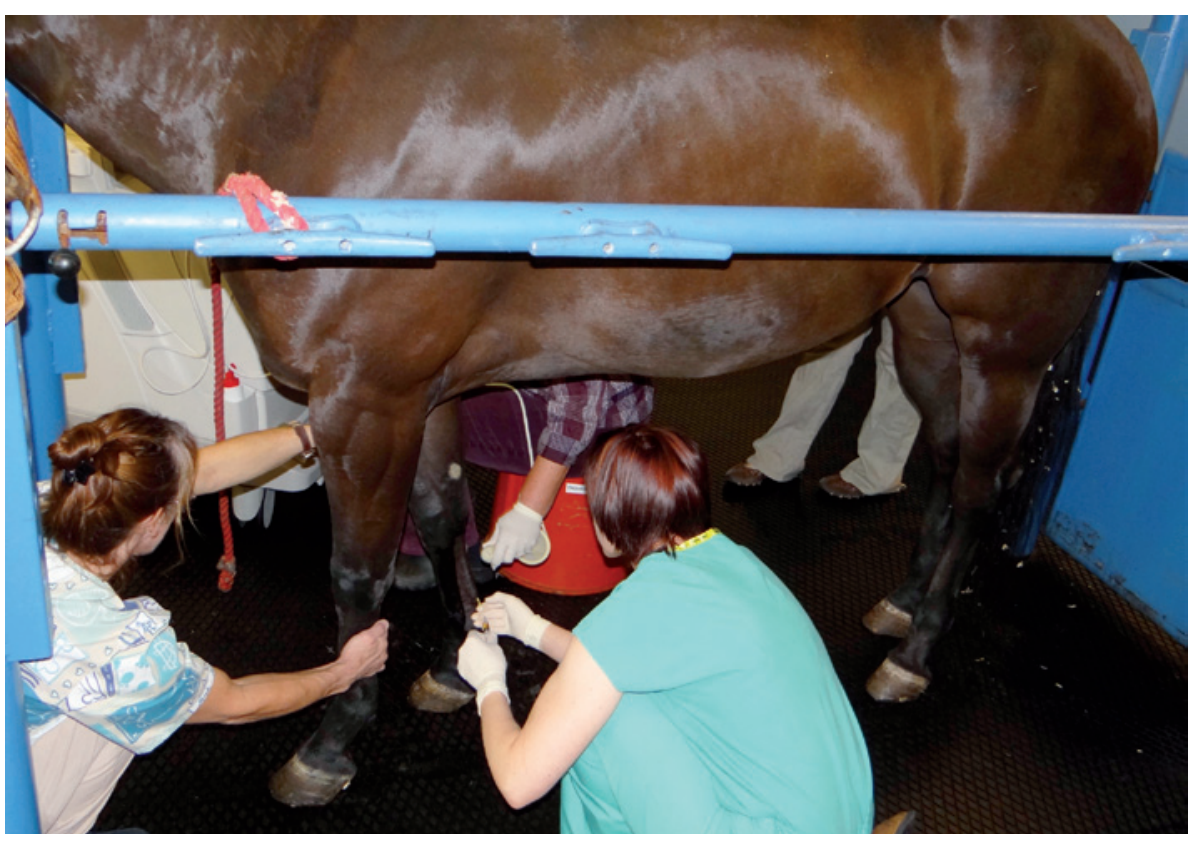

A horse is given an injection of stem cells in a bid to promote healing in a tendon injury.

REGENERATIVE MEDICINE

\title{
Stem cells boom in vet clinics
}

\section{Horses, dogs and even a tiger have received the unproven therapies. Now, drug regulators plan to weigh in.}

\section{BY DAVID CYRANOSKI}

$\mathrm{P}$ atients seeking unproven stem-cell therapies in the United States often run up against government restrictions. But Vintage 'Vinty' Mark of Lovettsville, Virginia, had no difficulty getting such injections to treat an injured tendon in his leg. The leg improved dramatically, and Vinty went back to training — to be a racehorse.

New guidance from the US Food and Drug Administration (FDA) could, however, soon rein in veterinary uses of stem cells, a practice that has exploded in the United States over the past decade, even though most therapies are unproven. Many researchers and veterinarians say that the guidance, a draft of which the agency plans to issue by the end of the year, is overdue. But others worry that FDA interference could hamper research that could benefit animals - and their human companions.

In the absence of clear regulations, the industry has burgeoned. Vet-Stem, a company based in Poway, California, has provided stem-cell treatments to more than 5,000 horses, 4,300 dogs and 120 cats since treating its first patient in 2004. Kits provided by MediVet America, based in Nicholasville, Kentucky, have been used to produce stem-cell injections for more than 10,000 horses since 2010. University veterinary departments, independently or through spin-off companies, have offered such services to thousands more animals. Veterinarians send patients' tissue samples to the centres to have cells extracted or, increasingly, turn to kits that allow them to extract the cells in-house.

Stem cells are most often used to treat horses, dogs and cats, but clinicians have also sought to use them to repair a lumbar fracture in a Bengal tiger and arthritis in pigs. Researchers have also found stem cells in the fat of bottlenose dolphins, raising hopes for treating the marine-mammal versions of liver disease and type 2 diabetes. "There's not a large vet practice that's not using them," says Wesley Sutter, a veterinarian at Lexington Equine Surgery and Sports Medicine in Kentucky. "Some claim [the treatment] cures everything."
Many veterinarians offer unproven stemcell therapies to satisfy demanding customers, says Dori Borjesson, who specializes in veterinary medicine at the University of California Davis. "Clinicians are sucked into giving treatment" even when there's not research to back up uses, she says.

Like the treatments sought by humans, most of those used in animals involve mesenchymal stem cells (MSCs), which can mature into a wide variety of cell types, including bone and cartilage, and have been shown to have antiinflammatory and other beneficial effects. MSCs are extracted from fat or bone marrow and can be cultured or prepared for injection in concentrated form.

The FDA's position on the use of MSCs in humans is clear. It says that the cells are drugs and therefore must be proved safe and effective before they can be used in treatment, except under certain conditions. No MSC treatments have been approved. But the FDA has different regulations for veterinary medicine, and these do not clearly address MSCs. The agency has not approved any veterinary stem-cell therapies, but neither has it cracked down on any. This is in stark contrast to its high-profile actions against purveyors of unproven human stem-cell treatments, such as Celltex Therapeutics of Sugar Land, Texas, which treated patients with MSCs until the FDA stepped in last September.

That doesn't mean that the agency is not concerned, says Lynne Boxer, a veterinary medical officer in the FDA's Office of New Animal Drug Evaluation in Rockville, Maryland. "As with any type of drug product, there are risks and benefits," she says. "With stem cells, there is the potential for disease transmission and tumour formation." She declines, however, to say whether current practices are against FDA rules, or to elaborate on what the new draft guidance is likely to contain.

The guidance void is irksome, says Karl Nobert, a lawyer at Squire Sanders in Washington DC, who has represented companies seeking direction from the FDA. His concern is not just professional: he is Vinty's former owner, and says that he saw "incredible improvement" as the horse healed, with normal tendon fibres rather than scar tissue at the injury site.

Research backs up the benefits of stemcell treatments in some applications. A 2007 double-blind study in 21 dogs showed that MSCs improved chronic osteoarthritis ${ }^{1}$. A 2010 report showed that injections of tissue rich in MSCs helped damaged leg bones to heal in 12 horses ${ }^{2}$. And a 2012 study, much discussed by veterinarians, showed that MSCs from bone marrow helped racehorses with tendon injuries avoid re-injury ${ }^{3}$.

Researchers recognize that many studies of veterinary stem-cell treatments have a major weakness: they lack control groups or blinded evaluation, which are crucial to show whether the treatments truly make a difference. "It is 
exceptionally difficult to do blinded studies in our patients because the owners or trainers specifically seek an institution for stem-cell therapy," says Lisa Fortier, a veterinary surgeon at Cornell University in Ithaca, New York, and a co-author of the 2010 cartilage study.

Without controlled trials, comparisons between treated and untreated animals are difficult. Owners who have paid a few thousand dollars for a therapy are more likely to follow strict rehabilitation protocols than those who have not. They are also more likely to rush horses back into action, which would skew reported recovery time, a measure of a treatment's effectiveness. And placebo effects - on the owners can be powerful. "The cat looks like hell to me but the owner says: 'She looks so great. I love stem cells'” says Borjesson.

Many veterinarians think that studying stem-cell therapies in large animals, which are more physiologically similar to humans than the mice often used in preclinical research, could be a powerful model for medicine - if studies are done right. Borjesson is running studies (with "as much blinding as possible") of stem-cell treatments for dry eye, another eye condition called recurrent uveitis, and inflammatory bowel disease in clients' pet dogs. She is also collaborating with researchers in human regenerative medicine, so that her findings can inform their studies of experimental therapies. And David Frisbie, a veterinary surgeon at Colorado State University in Fort Collins, is working with doctors to apply lessons from animal stem-cell treatments to joint injuries in humans.

If the pending FDA guidance clearly designates animal stem cells as drugs, veterinarians and companies who want to deploy such treatments will first have to conduct clinical trials, which Frisbie estimates could cost at least US $\$ 5$ million each. Nobert, meanwhile, is optimistic that veterinary stem-cell companies and university researchers will find ways to "design creative regulatory approval strategies to streamline and expedite the review-andapproval process" - which might, in turn, influence the human stem-cell regulatory process.

Still, he worries that overly stringent FDA rules about, for example, how cells are characterized, could "make the ultimate commercial price unreasonable".

For Vinty, it's a moot point. He's had his stem cells. But even with his tendon fixed, he was too slow to race. He now gives riding lessons to children.

1. Black, L. L. et al. Vet. Ther. 8, 272-284 (2007).

2. Fortier, L. A. et al. J. Bone Joint. Surg. Am. 18, 1927-1937 (2010).

3. Godwin, E. E., Young, N. J., Dudhia, J., Beamish, I. C. \& Smith, R. K. W. Equine Vet. J. 44, 25-32 (2012).

\section{Budget forces tough look at biodefence}

\section{US supply stockpile for combating bioterror attacks and pandemics feels the strain of funding cuts.}

\section{BY ERIKA CHECK HAYDEN}

B udget cuts mean painful choices for managers of the US Strategic National Stockpile, a medical repository initially designed to aid the country's response to terrorist attacks.

Congress created a national stockpile in 1998, and this has grown into an all-purpose resource that can deliver supplies to a disaster site within 12 hours. But the federal budget crisis has reduced the stockpile's funding by $18 \%$ over the past four years (see 'Running Low'), raising doubts about whether the United States can afford to be prepared for every pandemic or natural disaster, from bird flu to hurricanes.

At a 3 April meeting, advisers to the Department of Health and Human Services (DHHS) unanimously endorsed a report recommending that the stockpile rely on science to guide decisions about what threats are most likely, what supplies are needed to respond and whether local officials can actually use them. "The [stockpile] will be buying less. There's no doubt about it," said Ali Khan, who directs the public health and preparedness office at the US Centers for Disease Control and Prevention in Atlanta, Georgia, which oversees the stockpile.

Federal officials are struggling to weigh up competing priorities. State and local disaster-response agencies increasingly rely on the stockpile to compensate for cuts to their own budgets. But the national programme is also the only buyer for expensive, specialized treatments developed after the 2001 World

\section{RUNNING LOW}

Strong financial support for the Strategic National Stockpile has given way to harsh budget reality.

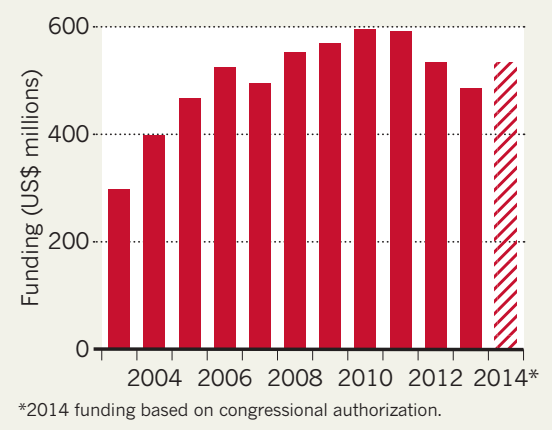

Trade Center and anthrax terrorist attacks. It is spending increasing amounts on therapies that are unlikely ever to be used.

"There has clearly been mission creep," said Steve Krug, director of emergency medicine at the Ann \& Robert H. Lurie Children's Hospital of Chicago in Illinois at the 3 April meeting.

The DHHS has already sharply reduced orders for some items, including a new botulism antitoxin that costs US $\$ 1,250$ per dose. Such decisions alarm companies making biodefence products, says Maureen Hardwick, executive secretary of the Alliance for Biosecurity in Washington DC, which represents many of those firms. "If they're researching and developing things that will not be procured, that sends a negative signal," Hardwick says.

But just replacing expired medications already in the stockpile will exceed the repository's projected budget by $20 \%$ next year. And the programme will eventually be asked to restock other high-priced anti-bioterrorism drugs first purchased by a separate agency, the Biomedical Advanced Research and Development Authority (BARDA), which supports the development of medications considered priorities for biosecurity.

BARDA has purchased 2 million doses of an anti-smallpox drug for more than $\$ 150$ per dose, even though the stockpile already contains enough smallpox vaccine to immunize the entire US population.

The stockpile will also foot the bill for two biological products to neutralize the toxin produced by anthrax bacteria, first purchased by BARDA at costs of $\$ 2,900-3,500$ and $\$ 8,100$ per dose. Meanwhile, the country continues to invest in biodefence research.

Fewer purchases may mean that the United States will be less prepared for unlikely events, such as bioterrorist attacks, than officials would like. But other nations made this trade-off long ago. Only two other countries - Japan and Israel - are thought to have enough smallpox vaccine to vaccinate their entire populations. And no other country has anything like the anti-bioterrorism arsenal of the United States.

"There has to be a thoughtful analysis of what we're willing to do without, which is a very painful discussion in our society," Krug said at the meeting. 